\title{
Methodical basis of the needs of water supply in rural areas in normal and special conditions
}

\author{
Mikołaj Sikorski ${ }^{1}$, and Hanna Bauman-Kaszubska ${ }^{1, *}$ \\ ${ }^{1}$ Faculty of Civil Engineering, Mechanics and Petrochemistry, The Warsaw University of Technology, Łukasiewicza 17, 09-400 Płock, \\ Poland
}

\begin{abstract}
When calculating the balance of water supply, the purpose for which water is intended should be taken into account. Depending on them, the water quality parameters may vary. Rural and agricultural water demand covers the basic types of water demand, including the population's living and economic needs, animal husbandry, the needs of public utilities, the needs related to the operation of vehicles and machinery, workshops, machines and other purposes, including the own needs of the water pipes, fire-fighting etc. The level of demand is also closely related to the factors influencing the level of individual water consumption. Taking into account the deficiencies in formal and legal regulations, the binding regulations concerning the operation of water supply systems in special conditions have been presented so far. Elements of the benchmarking study on unit water demand indicators in normal and special conditions in rural areas have also been taken into account, guided by the principles and numerical indicators for the calculation of water demand for drinking and business purposes.
\end{abstract}

\section{Introduction}

The role and importance of water is by its users usually adopted as the fulfillment of basic living and economic needs. This awareness, based on daily living, generally increases in cases of lack of access to water sources and the need to bring it sometimes from quite considerable distances, as well as in emergency situations, natural disasters and other hazards.

Waste and lack of respect for water are accompanied by easy and unrestricted access to it. Contaminated water used to water animals can cause many illnesses and even collapsing. Chemicals such as nitrates and pathogens (bacteria, viruses, worms, etc.) that cause poisoning and animal diseases are particularly dangerous.

It can be said that water is a basic and indispensable factor for the health and well-being of a farmer and his family and the basic factor of agricultural, vegetal, animal and processing production. Only clean water of good quality is useful.

The basic element in water management, including rural areas, is to save water consumption and prevent water pollution, regardless of where they occur.

The water supply of rural areas is characterized by many water requirements, including, among others, the needs of living and economic purposes, animal husbandry, public utilities, agricultural and agri-food processing plants, washing of agricultural equipment and vehicles, workshops as well as other needs.

For rural settlement units and agricultural centres, the demand for animal husbandry and living and economic purposes are the decisive factors that play a fundamental role in shaping water abstraction, and thus affecting the size of technological facilities in water treatment plants. The related unit water demand rates depend on many factors, including the standard of sanitation of households, the equipping of households with sanitary utensils, the equipping of these units with collective or individual sanitation facilities, as well as the size of animal husbandry, the size and intensity of animal production, and many other factors.

The functioning of the water supply system is connected with the possibility of threatening human health or life, and the failures that occur often lead to catastrophic consequences [1]. As a part of the water supply system security, it is necessary to monitor continuously operational statuses and identify adverse events together with procedures for responding to such events [2].

\section{Legal and formal bases}

Water management issues in the country are governed generally by the Water Law Act of 18 July 2001 [3], as well as on the technical and organizational side by the Act of 7 June 2001 on Collective Water Supply and Collective Sewage Disposal [4] and Legal acts related to these laws.

Basic legal regulations related to the above issues have undergone a kind of evolution, which was influenced, among other things, by the actual amounts of water consumption for the objectives, charges for water intake, as well as rational conditions justifying the need to unify the scale of unit water demand indicators at the

Corresponding author: Hanna.Bauman@pw.edu.pl 
national level. For the purposes of drawing up the balance of demand and water consumption under normal conditions, the Regulation of the Minister of Infrastructure of 14 January 2002 on average water consumption standards [5] shall apply. It should be noted that in the so-called special conditions, the amount of water demand and consumption is determined in accordance with the following legal regulations, i.e. in:

- Regulation of the Minister of Spatial Economy and Construction of 21 September 1995 on the principles of ensuring the functioning of public water supply facilities in special conditions [6],

- Regulation of the Council of Ministers of 25 June 2002 on the detailed scope of activities of the Chief of the National Civil Protection, chiefs of civil defense of voivodships, countries and communes [7].

This issue was also addressed in publications [8-12]. These are the experiences of national science and practice related to the role of water in human and animal life.

The aforementioned MSEC decree [6] and its amendment, as laid down in the 2002 Council of Ministers decree [7] concerns the following:

- municipal and rural waterworks,

- industrial waterworks,

- emergency wells.

A limited period of water supply is defined as the condition during which reduced water supplies occur, with a possible decrease in quality parameters. In the period of limited water supply caused by external factors (failures, natural disasters, state of danger and possible war, etc.) one should consider:

- the necessary delivery period of several weeks,

- the minimum delivery period of several days.

The necessary amount of water supplied during a limited supply period is determined by the amount of water that covers the needs of all consumers in the quantities necessary for life, functioning of public utility plants and the needs of the selected production. The minimum quantity of water supplied during a limited supply period, on the other hand, is defined as the quantity of water that covers the survival needs of the population and livestock. Public wells should be understood as wells made on the basis of the Ordinance of the Council of Ministers of 23 December 1986 on water supply facilities and sewerage facilities, as well as water charges and wastewater disposal charges [13].

\section{Unit water demand ratios}

Available bibliographic data [14-17] demonstrate the occurrence of much smaller unit water consumption from those given by the guidelines and the continued downward trend in both individual farms and entire water supply systems. There is therefore a need for research in rural areas, not only in typical agricultural holdings, but also in the rest of the population. The key question is what are the indicators of the individual water intake occurring in them and how much an increase in the share of this type of consumers affects the height and specificity of water intake from rural water systems [18].

During the period of essential water supply, public water supply facilities shall ensure that the following needs are met:

- population $q_{u}=15 \mathrm{dm}^{3} / \mathrm{res} \cdot \mathrm{d}$;

- food industry and other plants whose functioning is necessary to ensure the survival of the population individually depending on the needs of the planned volume of production in special conditions (with the separation of plants which source water from their own water supply systems);

- public utility plants with $50 \%$ of the normal water demand;

- decontamination and deactivation, including for the following purposes:

a) $45 \mathrm{dm}^{3} /$ person of the permanent and field sanitary treatment institutions,

b) stationary and field clothing decontamination units in a quantity of $40 \mathrm{dm}^{3} / 1 \mathrm{~kg}$ of disinfected clothes,

c) stationary and field transport decontamination units in a quantity of $200-500 \mathrm{dm}^{3} / 1$ vehicle depending on the vehicle size,

d) stationary and field veterinary posts in the following quantities:

- for a large animal $20 \div 25 \mathrm{dm}^{3} / 1$ animal,

- per sheep, goat $12 \div 15 \mathrm{dm}^{3} / 1$ animal,

- for pigstock 4-5 $\mathrm{dm}^{3} / 1$ animal,

with higher values to be taken into account for the calculation of the necessary amount of water;

- land and technological facilities - $15 \%$ of the water produced at that time.

The amount of water for fire-fighting purposes is determined in accordance with the needs and specifications of the area, according to the regulations of the fire brigade's field commands.

During the period of supply of minimum quantities of water, public water supply facilities shall ensure that the following needs are met:

- population - in the number of $7.5 \mathrm{dm}^{3} / \mathrm{res} \cdot \mathrm{d}$,

- livestock animals as indicated in Fig. 1,

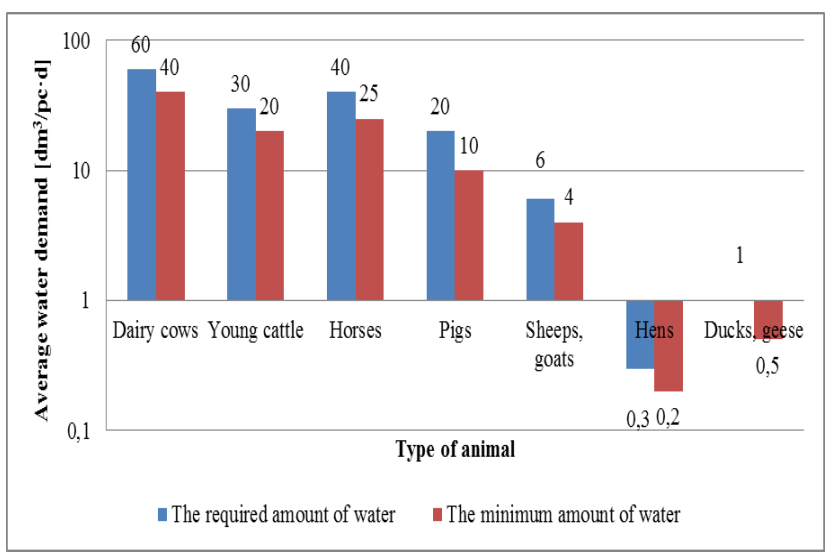

Fig. 1. Average water demand indicators for farm animals during the limited water supply [made on the basis 22].

- sanitary and veterinary treatment points,

- water requirements for the decontamination and deactivation of humans and animals during the minimum amount of water should be set at $50 \%$ of the calculated 
demand - in accordance with the recommendations concerning the so-called necessary amounts of water. Generally, all animals should have permanent, unlimited access to the water. Insufficient amount of this constituent limits animal feed intake, which in turn makes production quality worse. The water requirements for livestock are quite varied, depending on the species and age of the animals, as well as the watering system (animal installations with water supply and drinking troughs and no installations). According to the scientific opinion [8-9] and the practice of the zootechnical services, particular attention should be paid to the proposed unit amount of water for young cattle. It seems [19-20], that the so-called minimum quantity of water $\left(q_{\min }\right)$ for this age group of animals should be increased, from the MSPC's 1995 regulation [6] so far proposed, from $q_{\min }=20 \mathrm{dm}^{3} /$ animal index by $\min$. $50 \%$, i.e. to $q_{\min }$ rect. $=30 \mathrm{dm}^{3} /$ animal, where $q_{\text {min rect. }}$ is rectified minimum quantity of water. This is due, among other things, to the reasons for survival and counteracting the degeneration of this age group of cattle. It also appears that in critical situations - the absolute minimum public water supply the unit rate may reach a value of $q_{\min }=3 \mathrm{dm}^{3} / \mathrm{res} \cdot \mathrm{d}$, but only for a period not exceeding 3 days. After this period, the water supply of $q_{\min }=7.5 \mathrm{dm}^{3} / \mathrm{res} \cdot \mathrm{d}$ should be increased.

When calculating the required water requirement and minimum water quantity, the coefficient of unevenness of water distribution per day $\left(N_{d}\right)$ should be taken into account in the value of $N_{d}=1.1$. For a limited water supply period, $15 \%$ should be taken into account - in addition to the calculated average daily necessary and minimum water requirements. In turn, the approximate values of coefficient of unevenness of daily water distribution are as follows $[12,19]$ :

- $N_{d}=1.5$ for animals: horses, cattle, pigs;

- $N_{d}=1.3$ for other groups of animals, including: goats, sheep, poultry, nutrias, foxes and mink, rabbits.

The average values of the coefficient of unevenness of hourly water decomposition are as follows [10]:

- $N_{h}=3.0$ for all types of animals by watering them from the water supply system in the livestock building;

- $N_{h}=4.5$ by watering animals (horses, cattle, pigs) without water supply system.

According to the studies [20] it was suggested that the so-called integrated indicators of water demand and wastewater discharged were adopted, which are the result of many years of ILRGF (The Institute for Land Reclamation and Grassland Forming) research and trends of the actual decrease of water consumption in rural settlement units covered by the collective water supply. Integrated indicators of the demand for water and the amount of household and economic wastewater from rural units cover the relevant needs of households, small dispersed institutions, public utilities (commune offices, schools, shops, artisanal service points) without taking into account the demand for water for watering garden plots, herbal plots, crop spraying (plant spraying), cooling wastewater, vehicle washing and agricultural equipment (aside from buildings). It has been assumed that the water demand according to the so-called integrated indicators will be $100 \%$ equivalent to the amount of sewage generated.

The second assumption is to take into account the value of the coefficient of unevenness of wastewater outflow $N_{d \text { sew san. }}$ reduced by approx. $20 \%$ compared to $N_{d \text { water }}$.

Also the concept was adopted assuming that, for the calculation of water requirement and the amount of generated municipal wastewater from a dedicated business unit located in the village, if less than $30 \%$ of the total demand, and the amount of wastewater, the units are not included in the tables of summary (water and sewage).

For such assumptions integrated indicators of water demand and household sewage drainage would shape up as follows [21]:

- municipal settlements and villages with developed services, including recreational ones

$q_{u_{\text {integr. }}}=250 \mathrm{dm}^{3} / \mathrm{res} \cdot \mathrm{d}$
$N_{h}=1.8$

- the other housing classified into public water supply

$\begin{array}{cc}q_{u}=1.1 \quad & q_{\text {integr. }}=200 \mathrm{dm}^{3} / \mathrm{res} \cdot \mathrm{d} \\ N_{h}=2.0\end{array}$

- estates qualified for an individual water supply

$q_{\text {u integr. }}=160 \mathrm{dm}^{3} / \mathrm{res} \cdot \mathrm{d}$
$N_{h}=1.2 \quad 1.6 \div 2.0$

where:

$q_{\text {u integr. }}$ - unit integrated water demand indicator;

$N_{d}$ - daily coefficient of unevenness;

$N_{h}$ - hourly coefficient of unevenness.

In the case of adoption of the extended scope of the demand for water, consumers supplied with communal water systems in rural areas, i.e. in relation to the aforementioned assumptions about the needs of the animal husbandry operation of vehicles and machinery, watering home gardens, values of integrated indicators will increase to amount [20]:

- $q_{u \text { integr. }}=400 \mathrm{dm}^{3} / \mathrm{res} \cdot \mathrm{d}$ for municipal housing with decreasing tendency to approx. $q_{\text {u integr. }}=300 \mathrm{dm}^{3} / \mathrm{res} \cdot \mathrm{d}$ and rural with well-developed services (including recreational villages);

- $q_{u \text { integr. }}=300 \mathrm{dm}^{3} / \mathrm{res} \cdot \mathrm{d}$ for other units of decreasing tendency to approx. $q_{\text {u integr. }}=250 \mathrm{dm}^{3} / \mathrm{res} \cdot \mathrm{d}$.

The demand for water for the water-absorbent facilities, i.e., those in which water needs exceed $Q_{\text {dayaverage }} \geq 50 \mathrm{~m}^{3} / \mathrm{d}\left(Q_{\text {day average }}\right.$ - average daily water demand) and the livestock farms with the density exceeding $100 \mathrm{LU}$ (LSU, Livestock Unit) is calculated separately and added to the water demand for the individual as calculated from the integrated water demand standards $[10,20]$.

$1 \mathrm{LU}$ value is an animal having a body weight of 500 $\mathrm{kg}$ or a number of animals with total body weight of 500 $\mathrm{kg}$. It is also important to consider other indicators in terms of conversion techniques, e.g. large manure unit (LMU), which produces 10 tons of manure and a large feed unit (LFU), which means that it consumes 3500 
ounces of oats. The conversion factor for $\mathrm{LU}$ is commonly used, but the conversion of the LMU and LFU of animals allows you to calculate specific water requirements for specific purposes. The calculations made by the authors make it possible to conclude that the largest daily average water consumption is for large manure unit, and the water requirement for large units is higher for pigs than for cattle.

General water demand (as $Q_{\text {day average }}$ ) for the animals in special conditions, according to the author, can be calculated using the following relationship:

$Q_{\text {day average }}=a_{1} \cdot N_{1}+a_{2} \cdot N_{2}+\ldots+a_{n} \cdot N_{n},\left(\mathrm{~m}^{3} / \mathrm{d}\right)$

where:

$a_{1}, a_{2}, a_{n}$ - individual indicators of water demand for each group of animals, expressed in $\mathrm{m}^{3} /$ piece $\cdot \mathrm{d}$;

$N_{1}, N_{2} \ldots . N_{n}$ - number of animals in each group.

When expressed in terms of water demand indicators for individual animal groups in $\mathrm{dm}^{3} /$ animal $\cdot d$, formula (4) shall be given as follows:

$$
\begin{array}{r}
Q_{\text {day average }}=10^{-3}\left(a_{1} \cdot N_{1}+a_{2} \cdot N_{2}+\ldots+a_{n} \cdot N_{n}\right),\left(\mathrm{m}^{3} / \mathrm{d}\right) \\
Q_{\text {day } \max }=Q_{\text {day average }} \cdot N_{d},\left(\mathrm{~m}^{3} / \mathrm{d}\right)
\end{array}
$$$$
\text { assuming } N_{d}=1.1 \text {. }
$$

\section{The example of the balance of the average amount of water required for breeding the selected livestock}

Calculations of the average amount of water needed for breeding (Table 1) were carried out for selected examples of two groups of animals, i.e. pigs and poultry. The full balance sheet can be carried out taking into account other animal groups: cattle, including cows, sheep and others. Both extensive and intensive animal husbandry was established, with $67 \%$ and $33 \%$, respectively. The number of animals was adopted on the basis of 2015 data [22]. Taking into account the total number of animals, we can observe a downward trend in the case of pigs, with the number of 10590.2 thousand in December 2015 and a systematic increase in the number of poultry at the level of 153,177.4 thousand.

Conducted studies and analysis showed that the overall average annual water requirement for livestock under inadequate water supply is around $50 \%$ of normal demand. The average amount of water used for breeding pigs and poultry only under conditions of limited water supply is approximately $68 \%$ of the water requirement under normal water supply conditions.

In both cases of the conditions of the water supply, the main item in the structure of the overall water demand during the year is feeding and watering animals. For the cases considered, this is $64 \%$ in normal conditions and up to $81 \%$ in special conditions. Animal health and animal housing makes a total of $33 \%$ of the total demand in normal conditions, but in special conditions this position, referring mainly to disinfection and deactivation of the animal rooms is only $14 \%$ of the total requirement.

\section{Summary}

The adoption of specific water demand indicators is based on the objective for which they are adopted. The development of livestock farming depends, among other things, on equipping livestock facilities with water supply and sewage systems, which include watering animals, preparation of fodder, maintenance of animal hygiene and housing.

\begin{tabular}{|c|c|c|c|c|c|c|c|c|c|c|c|}
\hline \multirow{4}{*}{$\begin{array}{c}\text { Type } \\
\text { of } \\
\text { animals }\end{array}$} & \multirow{4}{*}{$\begin{array}{l}\text { Quantity } \\
\text { of animals } \\
\text { [mln of } \\
\text { pcs] }\end{array}$} & \multicolumn{10}{|c|}{ Average amount of required water } \\
\hline & & \multicolumn{10}{|c|}{ Conditions for unlimited water supply } \\
\hline & & \multicolumn{5}{|c|}{ Indicators $\left[\mathrm{dm}^{3} / \mathrm{pc} \cdot \mathrm{d}\right]$} & \multicolumn{5}{|c|}{ Total in a year $\left[\mathrm{mln} \mathrm{m}^{3}\right]$} \\
\hline & & $\begin{array}{c}\text { Feeding } \\
\text { and } \\
\text { watering }\end{array}$ & $\begin{array}{l}\text { Animal } \\
\text { hygiene }\end{array}$ & $\begin{array}{l}\text { Premises } \\
\text { hygiene }\end{array}$ & $\begin{array}{l}\text { Slaugh- } \\
\text { terhou- } \\
\text { ses }\end{array}$ & Total $^{1}$ & $\begin{array}{c}\text { Feeding } \\
\text { and } \\
\text { watering }\end{array}$ & $\begin{array}{c}\text { Animal } \\
\text { hygiene }\end{array}$ & $\begin{array}{c}\text { Premises } \\
\text { hygiene }\end{array}$ & \begin{tabular}{|c|} 
Slaugh- \\
terhouses
\end{tabular} & Total \\
\hline \multicolumn{12}{|c|}{ Extensive breeding } \\
\hline Pigs & 7.06 & 20 & 2 & 3 & 500 & 25 & 51.54 & 5.15 & 7.73 & 3.53 & 67.95 \\
\hline Poultry & 102.14 & 0.5 & 0.2 & 0.3 & - & 1.0 & 18.64 & 7.46 & 11.18 & - & 37.28 \\
\hline \multicolumn{12}{|c|}{ Intensive breeding } \\
\hline Pigs & 3.53 & 22 & 3 & 5 & 500 & 30 & 28.35 & 3.87 & 6.44 & 1.77 & 40.43 \\
\hline Poultry & 51.07 & 0.6 & 0.3 & 0.5 & - & 1.4 & 11.18 & 5.59 & 9.32 & - & 26.09 \\
\hline \multicolumn{12}{|c|}{ TOTAL $171.75 \mathrm{mln} \mathrm{m}^{3} / \mathrm{y}$} \\
\hline \multicolumn{12}{|c|}{ Conditions for limited water supply } \\
\hline $\begin{array}{c}\text { Type } \\
\text { of } \\
\text { animals }\end{array}$ & $\begin{array}{l}\text { Quantity } \\
\text { of animals } \\
\text { [mln of } \\
\text { pcs }]\end{array}$ & $\begin{array}{c}\text { Feeding } \\
\text { and } \\
\text { watering }\end{array}$ & $\begin{array}{r}\text { Hygi } \\
\text { deacti } \\
\text { anim } \\
\text { pre }\end{array}$ & $\begin{array}{l}\text { ne and } \\
\text { ation of } \\
\text { ls and } \\
\text { nises }\end{array}$ & $\begin{array}{l}\text { Slaugh- } \\
\text { terhou- } \\
\text { ses }\end{array}$ & $\begin{array}{c}\text { Total/ daily } \\
\text { (feeding and } \\
\text { watering) }\end{array}$ & $\begin{array}{c}\text { Feeding } \\
\text { and } \\
\text { watering }\end{array}$ & $\begin{array}{r}\text { Hygi } \\
\text { deacti } \\
\text { animals a }\end{array}$ & $\begin{array}{l}\text { ne and } \\
\text { ration of } \\
\text { d premises }\end{array}$ & $\begin{array}{l}\text { Slaugh- } \\
\text { terhouses }\end{array}$ & Total \\
\hline \multicolumn{12}{|c|}{ Extensive breeding } \\
\hline Pigs & 7.06 & 20 & & 5 & 500 & 20 & 51.54 & & .04 & 3.53 & 55.11 \\
\hline Poultry & 102.14 & 0.3 & & 3 & - & 0.6 & 11.18 & & .18 & - & 22.36 \\
\hline \multicolumn{12}{|c|}{ Intensive breeding } \\
\hline Pigs & 3.53 & 20 & & 5 & 500 & 20 & 25.77 & & 02 & 1.77 & 27.56 \\
\hline Poultry & 51.07 & 0.3 & & 3 & - & 0.6 & 5.59 & & 59 & - & 11.18 \\
\hline
\end{tabular}

Table 1. Summary of the average amount of water needed for animal husbandry.

${ }^{1}$ Total/daily with the exception of the slaughterhouses 
From the point of view of agricultural activity of rural farms focused on a specific specialization, in the field of water management, it is important to operate the unit water demand indicators according to specialist literature or on the basis of a technological production project. In order to simplify the calculation of water demand and consumption, it is proposed to take the values of the aggregated indicators for rural areas into account.

Starting from the actual stocking of animals in physical arts, from their conversion into LSU in individual species and from the balance of water in conditions of danger or war, the integrated conversion factors LSU, LMU, LFU for cattle and pigs were determined. The average daily water demand for large manure, feeding and conversion units is:

- for cattle: $122 \mathrm{dm}^{3} / \mathrm{LMU}, 121 \mathrm{dm}^{3} / \mathrm{LFU}, 113 \mathrm{dm}^{3} / \mathrm{LSU}$; - for pigs: $379 \mathrm{dm}^{3} / \mathrm{LMU}, 169 \mathrm{dm}^{3} / \mathrm{LFU}, 350 \mathrm{dm}^{3} / \mathrm{LSU}$.

Differences in results are the result of the use of specific conversion factors and result from the animal population. Large pigs have a greater demand for water, as more pigs than individual cattle are needed to achieve one manure, nutrition or conversion unit. Calculations in this area allow to estimate for what purposes there is a need to provide more water. For both cattle and pigs, the largest water demand was demonstrated for a large manure unit. In accordance with the conversion factors used, ultimately the higher water demand for cattle was reached for the LFU and the lowest for the LSU, however, the values are close to each other. In the case of pigs, clearly higher values have been achieved for LMU and LSU, and in relation to them the water demand for a large nutritional piece is more than 2 times smaller.

The issues examined concerning the water requirements for animal husbandry should be continued and extended to include the supply of water for the population in special conditions. It is expected to confirm the fact that there are significant differences in the water demand in the individual conditions and this is due to the current needs of the population. Under normal conditions, the demand is not only for drinking water, but also for hygienic, sanitary, cooking and even recreational purposes. Under special conditions, these quantities should be limited to cover the needs for survival.

The above considerations concern the provision of water in quantitative terms, however, for a full analysis of the issue, the quality requirements of water used in rural areas and agriculture should be taken into account. It is justified to develop an in-depth analysis and assessment of the water quality impact with parameters exceeding the obligatory quality requirements in this respect, ie. toxic contamination, mineral compounds, water pathogenic infections, on the development, health and productivity of farm animals, which will be used for the purpose of developing safety recommendations in this respect. It can be assumed that if the water supply to animals is carried out from the same water supply system, from which water is drawn for the living and economic and drinking needs of the population, there is no need for a separate study of the quality of water used in livestock production. This applies in particular to breeding centres (including rural areas) equipped with water supply systems ensuring adequate water quality.

It is also justified to elaborate the principles of functioning of collective facilities and individual supply of water to villages in special conditions, including technical and design requirements, technical and operational requirements, as well as the rules of organization and functioning of collective and individual rural waterworks.

It is desirable to carry out an analysis of the possibilities of using water from drainage systems to supply drinking water for livestock.

\section{References}

1. J. Rak, L. Opychał, GWiTS, 11, (2009)

2. P. Dohnalik, Z. Jędrzejewski, Effective operation of water supply - reducing water losses (LEMTECH Konsulting, Kraków, 2004)

3. Act of 18 July 2001 Water Law (Journal of Laws, 2001, No. 115, item 1229) with later amendments [In Polish]

4. Act of 7 June 2001 on Collective Water Supply and Collective Sewage Disposal (Journal of Laws, 2001, No.72 item 747) with later amendments. [In Polish]

5. Regulation of the Minister of Infrastructure of 14 January 2002 on average standards for water consumption (Journal of Laws, 2002, No. 8, item 70) [In Polish]

6. Regulation of the Minister of Spatial Economy and Construction of 21 September 1995 on the principles of ensuring the functioning of public water supply facilities in special conditions (MP 1995 No. 59 item 663) [In Polish]

7. Regulation of the Council of Ministers of 25 June 2002 on the detailed scope of activities of the Chief of the National Civil Protection, chiefs of civil defense of voivodships, countries and communes (Journal of Laws, 2002, No. 96 item 850) [In Polish]

8. M. Sikorski, J. Simoni, Seminar Materials PZITS, ZP, 7/83, Sanitary Technique of the Village, 407 (1984)

9. W. Sawicki, Water and sewage (PWRiL, Warszawa, 1982) [In Polish]

10. W. Sawicki, Water in animal production (PWRiL, Biblioteka Wiadomości IMUZ, No. 40, Falenty, 1972) [In Polish]

11. W. Sawicki, Technical solutions for the supply of animals in pasture in water (Instructional materials, $\mathrm{Nr}$ 7. IMUZ, Falenty, 1975)

12. S. Drupka, M. Sikorski, The role of water in the production of essential plant and animal products and the potential to replace certain products in the event of a water shortage (IMUZ, Falenty, 1999) Technical report not published 
13. Regulation of the Council of Ministers of 23 December 1986 on water supply and sewage facilities, as well as charges for water and the introduction of wastewater (Journal of Laws, 1986, No. 47 item 234)

14. R. Błażejewski, A. Waack, Consumption of tap water in selected villages in the Poznan region (Scientific and Technical Conference on Water Supply in Cities and Villages, Tom III, 337-347, 1996) [In Polish]

15. P. Bugajski, G. Kaczor, Infrastruct. Ecol. Rural Areas, 2 (2005)

16. J. Pawełek, M. Długosz, Guidelines for calculation of water demand in rural areas in the light of the need for their amendment (Scientific and Technical Conference on Water Supply in Cities and Villages, Tom I, 73-79, 1998)

17. J. Pawełek, S. Satora, Agric. Eng. 8 (2001)

18. J. Pawełek, G. Kaczor, Infrastruct. Ecol. Rural Areas, 2 (2006)

19. M. Sikorski, The role and importance of water in agriculture and its impact on human and animal health (ILRGF, Falenty, 1996)

20. W. Sawicki, Methodology for drawing up regional programs for agriculture and rural water supply. Vol. I. Water supply (Instructional materials, No. 26, Falenty 1978), Vol. II. Sanitary sewage system (Instructional materials, No. 39, Falenty 1980)

21. M. Sikorski, M. Good farming practices. Spatial solutions of homesteads (Regional Centre for Advice on Agricultural and Rural Development, Przysiek, 2002)

22. Central Statistical Office of Poland, Farm animals in 2015 (2016) 